\title{
First Edition of the Lullius Lectures: Kitcher's Reconstruction in the Philosophy of Science
}

\author{
María José FRÁPOLLI and Jesús VEGA ENCABO
}

Received: 18.03.2013

Final version: 25.03 .2013

BIBLID [0495-4548 (2013) 28: 77; pp. 181-184]

ABSTRACT: This monographic section contains the three papers delivered by Philip Kitcher as Raimundus Lullius Lectures during the VII Conference of the Spanish Society of Logic, Methodology, and Philosophy of Science, that took place in Santiago de Compostela (July 18th-20th, 2012). It also includes three of the contributions presented to the Symposium on Kitcher's work in the same Conference.

Keywords: Kitcher; Raimundus Lullius Lectures; SLMFCE; Philosophy of Science.

RESUMEN: La sección monográfica contiene las tres Conferencias que Philip Kitcher impartió en el marco de la Primera Edición de las Conferencias Raimundus Lullius patrocinadas por la Sociedad de Lógica, Metodología y Filosofía de la Ciencia de España, en el VII Congreso de la Sociedad, celebrado en Santiago de Compostela, del 18-20 de Julio de 2012. Incluye también tres de los trabajos que se presentaron en el Symposium dedicado a la obra del Prof. Kitcher en ese congreso.

Palabras clave: Kitcher; Conferencias Raimundus Lullius; SLMFCE; Filosofía de la Ciencia.

This monographic section contains the three lectures that Professor Philip Kitcher delivered in the first edition of the Raimundus Lullius Lectures during the VII Conference of the Spanish Society for Logic, Methodology and Philosophy of Science (SLMFCE), which took place in Santiago de Compostela (July $18^{\text {th }}-20^{\text {th }}, 2012$ ). It also includes three papers selected from the contributions presented at this conference in a symposium on Kitcher's philosophy.

The Raimundus Lullius Lectures are promoted by the SLMFCE with the aim of recognizing the work and contributions of leading philosophers working in the areas of interest of the Society. A philosopher with a long trajectory is selected democratically from the candidates proposed by members of the SLMFCE. No one was surprised by the choice of Philip Kitcher for the first edition of the Lectures. He has been one of the most important and influential philosophers of the last decades. His comprehensive work on many different topics has contributed to setting the agenda within philosophy of science and beyond. The SLMFCE considers it an honor to have Philip Kitcher as its first Lullius' Lecturer.

It is far from our intention to draw here even a brief sketch of Philip Kitcher's philosophical trajectory. His contributions range from analysis of key metascientific concepts (such as explanation or confirmation) and debates on realism and scientific progress to philosophical incursions in special sciences such as mathematics, physics, biology or social sciences. Nevertheless, it may be worth highlighting the spirit that animated him with a clear commitment to philosophical naturalism and social engagement. Kitcher has constantly attempted to make visible in the public space a whole range of social consequences of scientific ideas and debates. 
This very same spirit animates the three lectures that Kitcher delivered in Santiago de Compostela as the first series of Lullius' Lectures under the title "Toward a Pragmatist Philosophy of Science". He places himself under the aegis of John Dewey and promotes a reconstruction in philosophy of science in a pragmatist key. This amounts to rejecting a philosophy of science that would fall prey to insulation, sterile specialization and social blindness. And there is nothing better for this purpose than coming to terms with the post-Hempelian tradition and honestly assessing the achievements of the general philosophy of science, mainly focused on the analysis and philosophical explanation of fundamental metascientific concepts. In a sense, Kitcher is dealing with his own philosophical past when he recognizes our failure in fulfilling the tasks in Hempel's agenda. The first lecture, "Problems and Changes", whose name doesn't evoke Hempel's 1950 paper by chance, acknowledges that all efforts to offer general explicata of fundamental concepts have come to a dead-end. But it is a relative failure; it is a failure only if one thinks "of the goal of philosophy of science in terms of the provision of completely general explicata" (p. 197), but it is no failure if one adopts a more pragmatist perspective, from which the analysis of metascientific concepts is meant to provide a tool-box, whose different tools can then be applied to particular problems in many research fields. In this sense, the post-Hempelian general philosophy of science is far from being a failure; it is just that now it is suffering from diminishing returns, stuck with technical puzzles without genuine relevance for scientific research or promotion of human well-being. Tools need to be polished in a local context, in their multiple particular uses. Kitcher advocates a metaphilosophical maxim in the lectures: philosophical discussion should help improve research, avoid the unfruitfulness of scholasticism, and address significant problems. The pragmatic maxim reappears over and over again in the lectures.

This attitude does not dissolve the general philosophy of science into special sciences. Far from that, Kitcher encourages us to follow its program in another domain. We have to be guided by the same pragmatic recommendation: one should not provide a maximally general theory of science but contribute to the effective improvement of research. It makes sense, however, to wonder which are the norms that rule collective research and how science viewed as a social institution interacts with other institutions in democratic societies. This is the key focus of the following two lectures. In "The Logic of Collective Discovery", Kitcher engages in a detailed discussion about the conditions to be fulfilled by an ideal scientific community that balances the two dimensions of consensus and diversity. Taking the credit economy as a startingpoint, Kitcher points out the difficulties that this model faces in accommodating the facets of both cooperation and concurrence that seem essential to its good working. The philosopher must examine the normative structure of the organization of science and its effects on collective research. Here again pragmatist themes are present, because among the purposes of the collective organization of research we will find the following: the search for significant truths, the need for collegiate certification of results, the focus on the temporal dynamics of research, and the balance between truthseeking and error-avoiding policies. We are not going to sum up here the detailed strategies to avoid failures that are examined by Kitcher in the last sections of his se- 
cond lecture. It is worth remembering that again, none of them must be considered as applicable to all domains in the same way.

The Lecture "Science among other institutions" addresses one of the most important issues in the recent philosophy of science: how to regard the place of science within the rest of our social institutions. At this point, debates about science and values or about the relations of science and democracy are brought together. The Deweyan inspiration becomes more visible here, because the purposes and aims of science cannot be severed from our ideas about collective well-being. Science is defined as "an institution that promotes human well-being" (p. 218). The reader will find in the third part of Kitcher's paper a reworking of his idea that the set of significant questions that science must pay attention to should emerge following the ideal of a "well-ordered science". Kitcher is confident that his conception helps to avoid two extremes: the potential tyranny of ignorance (when the judgments of significance are just left to uninformed citizens) and the biases of research elites, with the aim of effectively pursuing the collective good through a process of priority-choice for scientific research.

Kitcher is aware that he is proposing an ideal, but he expects that the ideal should help to draw the guidelines of possible action plans that would serve to correct the biases and mistakes present in much of contemporary scientific practice. Some suggestions along these lines can be found in the third lecture, as well as in two of the papers included to complete this volume and presented in the Symposium on Philip Kitcher's Philosophy during the conference of the SLMFCE. Arnon Keren, in his paper "Kitcher on Well-Ordered Science: Should Science Be Measured against the Outcomes of Ideal Democratic Deliberation" disputes the legitimacy of appealing to the "well-ordered science" ideal as a procedure, or standard of assessment, in order to answer questions about how to set the aims and priorities of research. Keren examines traditional arguments for justification of democracy and their application in the case of Kitcher's democratic ideal of science. He concludes that none of them gives any rationale for defending the idea that science agenda must be determined following the ideal democratic procedure proposed by Kitcher.

Maxence Gaillard, in his contribution, contrasts the model of the "well-ordered science" with the reality of participatory policies and the institutional frameworks where the debates are held. In his paper "The Governance of 'Well-Ordered Science', from Ideal Conversation to Public Debate", he presents the results of a case study focused on a public debate in France about the launching of national research programs in nanotechnology. He adequately stresses the difficulties one encounters in striking a balance between the three conditions an ideal conversation must have in Kitcher's model: full representativeness, well-informed people and mutual engagement. Many are the problems of adjusting an ideal and normative framework to the reality of scientific and social institutions.

The section closes with an original contribution by Bence Nanay, "From Philosophy of Science to Philosophy of Literature (and back) via Philosophy of Mind: Philip Kitcher's Philosophical Pendulum". Nanay argues for the continuity between Kitcher's work in philosophy of science and his recent contributions to the philosophical analysis of literary and musical works. Here again his metaphilosophical commitments 
are made explicit; Kitcher's pragmatic attitude is understood as a way of acknowledging the non-rational aspects of our lives. The use of literary and artistic works in philosophical analysis is not a subsidiary aspect in philosophical engagement with life and reflection. To understand this pragmatic turn, it is necessary to adopt an appropriate image of the psychology of the philosopher, where the focus is not just on "the mainstream 'dispassionate quest for the truth' model of reasoning" (p. 262). The philosopher has also to be animated by rich philosophical imagination. Maybe-one could claim-motivations are integral to philosophical argumentation and that is why an intellectual commitment cannot be severed from certain existential engagement when we do philosophy. No doubt, we have here a new pragmatist motto, this time inspired by James.

Philip Kitcher showed this very same existential engagement during the three days he delivered the Lullius Lectures in Santiago de Compostela. We want to express our gratitude to Professor Kitcher for having accepted our invitation to give the lectures, as well as for the philosophical commitment he has shown in the promotion of values such as democracy and rationality, and above all for the kindness with which he indulged us during the Conference.

We are also grateful to THEORLA. International Journal for Theory, History and Foundations of Science for publishing the contributions of the first edition of the Raimundus Lullius Lectures. We hope that the cooperation inaugurated with this issue between the SLMFCE and the Journal will have continuity and result in a series of monographic sections with original papers by the future invited lecturers and valuable contributions on their work.

María José Frápolli is Professor of Logic and Philosophy of Science, her main areas of interest are the philosophy of logic, and the philosophy of language. In her work, she has been concerned with the analysis of the notions of truth, of quantifier, of identity, and of logical constants. M.J. Frápolli is also interested in Pragmatism and has translated into Spanish the complete works of F. P. Ramsey.

Address: Departamento de Filosofía I, Edificio de la Facultad de Psicología, Campus de la Cartuja, 18011 Granada, Spain. E-mail: frapolli@ugr.es

Jesús Vega Encabo is Professor of Logic and Philosophy of Science in the Universidad Autónoma of Marid. His main areas of interest are epistemology, philosophy of mind, and philosophy of science and technology. He has published papers on technical knowledge, know-how, social epistemology, epistemic normativity and epistemic agency, among many other topics in epistemology. He is also interested in the metaphysics and epistemology of the artifactual world.

Address: Dept. de Lingüística, Lógica y Filosofía de la Ciencia, Facultad de Filosofía y Letras, Universidad Autónoma de Madrid, Crta. Colmenar, km. 15, Cantoblanco, 28049 Madrid, Spain. E-mail: jesus.vega@uam.es 